\begin{tabular}{c|c}
\multirow{2}{*}{ EESD'15 } & The $7^{\text {th }}$ International Conference on Engineering Education for Sustainable Development \\
\cline { 2 - 2 } & Vancouver, Canada, June 9 to 12, 2015
\end{tabular}

\title{
PRINCIPLES, IMPLEMENTATION AND RESULTS OF THE NEW ASSESSMENT AND ACCREDITATION SYSTEM „ENGINEERING EDUCATION FOR SUSTAINABLE INDUSTRIES”' (QUESTE-SI)
}

\author{
Jurgis K. Staniškis ${ }^{1}$, Eglè Katiliūtè ${ }^{1}$ \\ ${ }_{1}^{1}$ Kaunas University of Technology, Lithuania \\ 1 justa@ltu.It
}

\begin{abstract}
While the importance of evaluating the education of sustainable development programmes has been widely recognised, very limited information is available on the topic. QUESTE - SI project was funded by the European Commission under the Lifelong Learning programme ERASMUS (2010-2012). QUESTE - SI stands for "Quality system of European Scientific and Technical Education for Sustainable Industry". The project was coordinated by EFMD, the Management Education Network, and ENQHEEI, the European Network for Quality of Higher Engineering Education for Industry. The QUESTE - SI evaluation and accreditation focuses on the institutional unit (department) that is responsible for one or more programmes. A key point is to ensure that each graduate learns the sustainability aspects related to the concerned education domain. A fair evaluation of social responsibility and sustainability education is not limited to teaching and learning methods or curricular content - it depends on parallel efforts in all dimensions. The main objective of the paper is to present, analyse and discuss principles, implementation and results of the original assessment and accreditation system for higher engineering education. The system comprises all five roles of the university: education, research, infrastructure and management, students' involvement and society. More than 10 European science and technical universities have been accredited in accordance to the QUESTE - SI requirements. Kaunas University of Technology was represented by the Institute of Environmental Engineering with the M.Sc. Programme "Environmental Management and Cleaner Production" and the Ph.D. Programme "Environmental Engineering and Landscape Management". The Institute of Environmental Engineering has been awarded the highest ranking and has become a fertile basis for a larger pilot project. The paper presents principles, methodology, results of QUESTE-SI evaluation and accreditation and the experience of pilot institution.
\end{abstract}

\section{INTRODUCTION}

Traditional engineering education focuses on response to needs or demands of employers, industry and the marketplace. Such needs or demands, when focused on the acquisition of specific scientific and technological knowledge, practical skills, and competences, may result in a concise description of a limited set of learning objectives for an assessment. Currently, there is a growing concern for responsibility related to decisions that may have a negative impact on society, the environment and resources. Nonetheless, curricula reforms are still needed to better educate engineers on the implications that their work has on the environment and societies in our and future generations. A step to facilitate this is assessing the contribution of engineering education to sustainability (Watson et al. 2013). Over 600 universities worldwide have committed themselves towards sustainability by signing international agreements and conventions such as the Bologna Charter, the Halifax Declaration, the Talloires Declaration and the Copernicus Charter for Sustainable Development. It is hoped that these measures being of special interest to the signatories - may catalyse more systematic action (Filho et al. 2015; Lozano et al. 2013). 
Several tools have been developed to assess university sustainability so far, for instance, the Auditing Instrument for Sustainable Higher Education (AISHE) (Roorda 2010), the Graphical Assessment for Sustainability in Universities (GASU) tool (Lozano 2006), the Environmental Sustainability Assessment Questionnaire, and the EMS Self - Assessment (Shriberg 2002). Many of these tools are focused on improving the sustainability of campus operations. The STAUNCH system (Lozano and Young 2013) is aimed at helping universities to assess the depth and breadth of their SD-related curricula in a holistic and systematic way and to produce standardised and comparable results. A challenge that remains is how to assess the contribution and impact that curricula and university life may have on student personal life during studies and for their professional life in helping to make societies more sustainable.

In Australia, it was argued that a fundamental way to begin assessing whether universities were committed to sustainable development was to explore whether the universities and the business faculty/school vision, mission and graduate attribute statements espoused values related to sustainability. The research has revealed that it is crucial to ensure consistent institutional communication and policies in relation to education for sustainable development. When education for sustainable development is not integrated into all functions and levels within universities, the mere espousing of its virtues is just a hollow rhetoric (Lee at al. 2013). The UI GreenMetric Ranking of World Universities is one of the first attempts to make global ranking of university sustainable behaviour. Five criteria of ranking have been determined based on information provided by respective universities that demonstrates commitment to going green and being sustainable, namely environmental settings and infrastructure, energy and climate change, waste, water, and transportation. The system employs 42 indicators divided into five categories to determine the ranking scores. One of the advanced features of the UI GreenMetric is that the ranking can be sorted by campus setting (rural, semi-urban, urban, overall ranking) or by type of higher education institutions (comprehensive, specialized higher education institutions) in the overall ranking. By using this feature, each institution or end user can make a fair comparison and group universities by their scores (Suwartha and Sari 2013).

The findings of the study at the University Sains Malaysia revealed the four constructs that can be considered to assess the sustainability practices of the university from students' perception: community outreach, sustainability commitment \& monitoring, waste \& energy, and land use/ planning (Nejati and Nejati 2013). The world-wide survey of engineering students suggests that, overall, the level of knowledge and understanding of sustainable development is not satisfactory and that much more work is needed in educating engineering students in this field. While on average students appear to be relatively knowledgeable about environmental issues, it is apparent that significant knowledge gaps exist with respect to the other two (social and economic) components of sustainable development (Azapagic et al. 2005). Therefore, the evaluation and accreditation systems based on non-ranking overall assessment from one side and facilitate good practises exchange among institutions from another side are still missing.

\section{THE NEW EVALUATION AND ACCREDITATION SYSTEM QUESTE-SI: PRINCIPLES AND METHODOLOGY}

The QUESTE-SI project is focused on the evaluation of university-level engineering education with respect to strategy and action directed to the issue of social responsibility and sustainability. A prerequisite for participation in QUESTE-SI is evidence of an institutional quality assurance system which satisfies national Quality Assurance (QA) requirements. QUESTE-SI evaluation focuses on the institutional unit (department) that is responsible for one or more programmes. The unit may submit more than one program for evaluation, provided that they have a sustainability emphasis or a theme. All submitted programs should at least be in the formal planning or at implementation stage. A key point is to ensure that each graduate learns the sustainability aspects related to the concerned education domain. (http://plone.queste.eu/).

In some U.K. and Canadian universities sustainability engineering topics are moved from the "moregeneral" to the "more-specific". Students are no longer introduced to broad definitions of sustainable development or phenomenon of climate change. Instead, students are introduced to aspects of systems theory, industrial ecology, resilient and regenerative infrastructure, supply-chains, and 
global/humanitarian engineering (Nesbit et al. 2013). The list of topical areas for QUESTE-SI is open and unit may choose sustainability topics according to their interests, capacities and objectives. A fair evaluation of social responsibility and sustainability education (SRSE) should not be limited to teaching and learning methods or curricular content. SRSE cannot be developed in a vacuum; it depends upon parallel efforts in other dimensions: (i) education and curriculum, (ii) the institution, faculty, or unit, (iii) student involvement, (iv) research \& innovation in cooperation with industry. A strategy for SRSE education recognize that tomorrow's engineers will need new "transverse" skills such as crisis communication and management, policy analysis and formulation, interdisciplinary approaches to problem solving, but above all, a broader view of problems, their causes, consequences, and preventive solutions. Thus, a key point when defining and evaluating learning objectives is whether they include the ability to anticipate the consequences of decisions and to act appropriately (a proactive rather than reactive approach). Another principle to consider is "contextualization" or "contextual awareness". This means that an engineer has the breadth and depth of vision needed to understand why certain kinds of knowledge and skills are necessary and to view actions, problems, solutions and consequences in a broad context that may be scientific, technical, economic, legal or social in nature at the same time. The question for evaluation is whether the curriculum and methods of teaching and learning develop this awareness.

The institution should be a model of sustainable innovations, research and development, and sustainability culture. QUESTE-SI believes that attention should be given to the presence and realization of sustainability strategies at institutional and unit department. Active view of social responsibility and sustainability should be in the policy-making of educational institutions. It means that a well-defined short, middle and long-term strategy for sustainability should be in the institution. Institutional and department strategy should focus on objectives, planning, implementation, and on results that serve as performance indicators. The root of students' involvement is their active participation in the culture of social responsibility and sustainability that go beyond the formal curriculum. Such activities may be based in national, regional or community agencies, NGO's and volunteer organizations. Some outside activities may complement the curriculum as sources of information and experience, and may complement the use of problem-led or project-based learning techniques. In other words, QUESTE-SI is interested in activities that help to cultivate student interest and involvement in sustainability, for example, contact with industry, advising and information practices, and support extra- or co-curricular activities. In the research \& innovation dimension, a strategic direction for institutional and unit choices of sustainability topics for research and development should be demonstrated. This contemplates co-operation with industry, business firms, peer institutions, and research agencies, other institutions, and organisations. QUESTESI looks for evidence that R\&D activities also serve to enrich the curriculum, teaching and learning.

Recognition is given jointly to the institutional unit and programs to reflect the fact that recognition first applies to the evaluated programs. The QUESTE-SI approach to evaluation is multi-dimensional and has a developmental emphasis. With each of four sustainability dimensions, there is separate rating of the extent of progress toward the realization of specific objectives for the area. To emphasize the diversity and richness of institutional efforts, QUESTE-SI approach to recognition takes into account four dimensions: education \& curriculum, the institution \& unit, student involvement, and research \& innovation. Recognition is multilevel and multidimensional. Having passed over an initial threshold for recognition, institutions are rated separately and cited for achievement with each dimension (Philips and Budkowski 2010).

The QUESTE-SI award is conferred by a body in light of self-assessment report and auditors visit report and recommendations. The self-assessment report comprises three parts: (1) questions that require a brief and well-focussed narrative response, (2) an institutional inventory, and (3) a rating of progress in terms of objectives and indicators. QUESTE-SI is focused on the context for institution sustainability effort, the organization and development of SRSE-related programmes and activities, finally, the origins of strategic initiatives and the deployment of policies between institutional levels. An institutional inventory has to show where the efforts of unit are situated in an institutional context, and full range of topical or subject areas, joint efforts with other departments where teaching staff, support personnel, or facilities are shared. Parts 1 and 2 of the report are limited to approximately eight pages; part 3 requires filling a dozen of objectives per dimension in a tabular sheet, associated with elements of proofs. The evaluation 
produces a formative judgment on the extent to which the evaluated unit reaches or exceeds a threshold level of sustainability effort, overall and within each of the four dimensions. It is important to recognize the diversity of institutional choices, actions, and outcomes. The efforts of each institution will rest upon different assumptions. Thus, an institution that is strong even in one of four dimensions will be recognized for that effort (Philips and Budkowski 2010).

Different studies show that despite of formal theory, in the end, it is the educator's personal theory, selfconstructed, whether explicit or not, that influences his or her daily pedagogical choices. The ultimate goal of these interrelated dimensions of contemporary education is the development of responsible societies and sustainability is one of the expected outcomes (Sauve 1996). A panel of auditors was established for the QUESTE-SI evaluation. It was composed of former auditors for high educational institutions or engineering program managers, and included representatives of the industry. Its members were provided with specific evaluation kits and have been trained to audit institutions and to provide advice and guidance during the evaluation process. Each audit visit took place during two days plus a few hours for the preparatory meeting of the audit team consisting of three members, including the reporter. Some exchanges were engaged between the reporter and the institution before the visit for the clarification of some objectives or achievements. This allows very detailed sustainability and social responsibility analysis (in the case of good self-assessment report), or some kind of support to institutions in order to identify and clarify progress points under low performance (Rouvrais et al. 2014).

\section{$3 \quad$ RESULTS}

The project has surveyed various networks of academic institutions, rankings, quality assurance systems, and models to enhance the development of the triangle of knowledge to identify the awareness of and commitment to sustainability as a strategic approach to sustainability, including sustainability in the study programs, involvement of the European Institute of Innovation and Technology, membership in certain networks. More than ten European science and technical universities have been accredited in accordance to the QUESTE-SI requirements, for example, Brno University of Technology, KTH Royal Institute of Technology, Vienna University of Technology, Telecom Bretagne, Instituto Superior Tecnico (IST, Portugal). Kaunas University of Technology was represented by the Institute of Environmental Engineering with the M.Sc. program "Environmental Management and Cleaner Production" and Ph.D. program "Environmental Engineering and Landscape Management" (Staniškis 2012). A short summary of the assessment results in all four dimensions is presented below.

Institute of Environmental Engineering was recognised as the most successful department in KTU dealing with SRSE issues. The Institute has knowledge and capacity to provide substantial contribution in sustainable development process at Kaunas University of Technology acting as a source of knowledge on sustainability for the entire University. The Institute has developed strategic priorities and a strategic plan for the future based on the KTU strategy and takes into account the key sustainability issues. The MISSION of the Institute - to disseminate sustainable development principles in Lithuania and all over the world through application of innovative sustainable solutions by means of interdisciplinary research, topical studies and continuous spread of knowledge and values. VISION of the Institute - a unique international leader in the field of sustainability based on interdisciplinary research and advanced studies.

In the area of education and curriculum development, APINI combines a traditional education in the engineering sciences with studies in the natural and social sciences with the ultimate goal of educating scholars who are uniquely situated to undertake serious research and policy assessments to tackle sustainable development challenges. The M.Sc. and Ph.D. programmes include a set of rigorous core requirements in the engineering, social and natural sciences designed to provide a deep understanding of the interaction between in all three areas, and provide students with the flexibility to pursue in-depth research in a broad variety of environmental issues. The programmes' graduates have unique combination of diverse skills and deep insight into the most challenging problems of future human welfare. Together with experts from industry and governmental institutions, students in the programmes conduct research in a wide variety of areas including climate change and its social consequences, causes and solutions to extreme material and energy resources inefficiency, energy systems, water resources, waste management systems, ecosystems, corporate social responsibility, environmental economics and 
eco-design. Students also benefit from being part of APINI research programmes and projects that focus on sustainable development (see Table 1).

Table 1: Dimension 2: education \& curriculum

\begin{tabular}{|c|c|c|}
\hline & Objectives & Indicators or evidence \\
\hline $2 a$ & $\begin{array}{l}\text { The programme plan includes the scientific } \\
\text { /technical knowledge, practical skills, and non- } \\
\text { technical subjects essential for teaching and } \\
\text { learning sustainability in the context of the topical } \\
\text { target areas chosen by the faculty }\end{array}$ & $\begin{array}{l}\text { The programme documentation clearly } \\
\text { identifies the subjects to be taught, the } \\
\text { sustainability- related learning } \\
\text { objectives \& outcomes, and the way in } \\
\text { which outcomes will be assessed. }\end{array}$ \\
\hline $2 b$ & $\begin{array}{c}\text { The programme plan reflects an institutional or } \\
\text { department rationale for the selection of } \\
\text { sustainability-related topics, the associated } \\
\text { methodologies, techniques and tools, including the } \\
\text { use of project-based or problem-led education } \\
\text { techniques }\end{array}$ & $\begin{array}{c}\text { The documentation explains how, why, } \\
\text { and by whom these choices were } \\
\text { made, with particular attention to the } \\
\text { design of learning projects and } \\
\text { problems }\end{array}$ \\
\hline $2 c$ & $\begin{array}{l}\text { The teaching and learning plan comprehends the } \\
\text { "transverse skills" that graduates will need to } \\
\text { recognize and effectively deal with sustainability } \\
\text { problems }\end{array}$ & $\begin{array}{l}\text { The programme has identified what it } \\
\text { considers to be transverse skills. It is } \\
\text { clear why, where, and how such skills } \\
\text { will be developed and verified. }\end{array}$ \\
\hline $2 d$ & $\begin{array}{c}\text { The programmes under review are designed to give } \\
\text { graduates the broader "contextual awareness" } \\
\text { needed to deal with sustainability issues and } \\
\text { problems. }\end{array}$ & $\begin{array}{l}\text { Contextual Awareness is a "transverse } \\
\text { skill" that cuts across different } \\
\text { disciplines and types of problems. }\end{array}$ \\
\hline $2 e$ & $\begin{array}{c}\text { The institutional unit has taken steps to address } \\
\text { sustainability learning objectives, outcomes, and } \\
\text { competencies in the external quality assurance and } \\
\text { internal review systems }\end{array}$ & $\begin{array}{c}\text { Documents or reports for internal and/or } \\
\text { external quality assurance confirm that } \\
\text { sustainability teaching and learning is } \\
\text { suitably evaluated. }\end{array}$ \\
\hline
\end{tabular}

Many graduates pursue academic careers in interdisciplinary graduate and undergraduate programmes with focus on industry and the environment as well as in more traditional engineering disciplines. Others choose non-academic positions in governmental institutions, NGOs or private firms engaged in environmental and sustainable development projects. During 16 years of Ph.D. programme and 10 years M.Sc. programme, the emphasis was placed on research at the boundaries between social, natural and engineering sciences, and these programmes have become very popular and highly rated. Almost all Ph.D. graduates have accepted academic positions as tenure-track professors or post-doctoral fellows, or are employed at high-level positions in the private sector and governmental organisations.

Sustainable development is one of the major topics of APINI research. The monograph "Sustainable innovations in Lithuanian industry: development and implementation", written by APINI researchers presents more than 60 projects in the field of sustainable development and cleaner production implemented during the last decade. New projects start nearly every year, and most of them have a sustainability aspects covered. The research results presented in the programs' doctoral dissertations are based on integrative, interdisciplinary research that is needed to explore science and policy issues in the area of sustainable development. Integrated Assessment methods and concepts (e.g. transitions, modelling, scenario analysis) are instrumental to provide answers to the central questions of sustainable development (see Table 2). 
Table 2: Dimension 4: research \& innovation in cooperation with industry

\begin{tabular}{|c|c|c|}
\hline & Objectives & Indicators or evidence \\
\hline $4 a$ & $\begin{array}{l}\text { The research agenda of the institutional } \\
\text { unit/department includes subjects clearly } \\
\text { related to sustainability }\end{array}$ & $\begin{array}{l}\text { The institute has a credible estimate of the } \\
\text { percentage of its members teaching or doing } \\
\text { research on sustainability issues. (Such information } \\
\text { may be found in existing reports or publications.) }\end{array}$ \\
\hline $4 b$ & $\begin{array}{l}\text { The Institution (or its units) contributes to } \\
\text { sustainable development through formal } \\
\text { partnerships or working relationships at } \\
\text { regional, national or international levels }\end{array}$ & $\begin{array}{l}\text { There is evidence of such activity in institutional } \\
\text { and/or institute level reports, publications, and in } \\
\text { reports issued by external R\&D partners }\end{array}$ \\
\hline \multirow{3}{*}{$4 c$} & \multirow{3}{*}{$\begin{array}{l}\text { The institution, its schools, or units } \\
\text { produce a significant amount of credible } \\
\text { research or scholarship in the broad area } \\
\text { of sustainability }\end{array}$} & $\begin{array}{l}\text { The amount of institute research with sustainability } \\
\text { aspects very strong: }>61 \%)\end{array}$ \\
\hline & & Research has received external recognition. \\
\hline & & $\begin{array}{l}\text { The amount of student research with sustainability } \\
\text { aspects in the context of their academic } \\
\text { programmes very strong: }>61 \%)\end{array}$ \\
\hline \multirow[b]{2}{*}{$4 d$} & $\begin{array}{c}\text { The unit has active and specific linkages } \\
\text { with industry, technological business, and } \\
\text { the engineering profession }\end{array}$ & $\begin{array}{c}\text { Evidence of specific linkages is found in university } \\
\text { and institute reports and publications, as well as in } \\
\text { materials produced by external partners }\end{array}$ \\
\hline & $\begin{array}{l}\text { Such links are a source of useful current } \\
\text { information on sustainability problems, } \\
\text { issues, and possible solutions }\end{array}$ & $\begin{array}{l}\text { The institute and programmes demonstrate that } \\
\text { information obtained via external links has been } \\
\text { applied to the benefit of teaching \& learning. (This } \\
\text { was observed in several well-chosen examples) }\end{array}$ \\
\hline $4 e$ & $\begin{array}{l}\text { The engineering school and unit are } \\
\text { visibly involved in associations, } \\
\text { professional or technical bodies and } \\
\text { organizations that are actively committed } \\
\text { to sustainability. }\end{array}$ & $\begin{array}{l}\text { There is evidence that external activities have had a } \\
\text { positive effect on the conception, planning, and } \\
\text { development of sustainability strategies within the } \\
\text { institution and its units. The issue is what was } \\
\text { learned in this way and applied. }\end{array}$ \\
\hline $4 f$ & $\begin{array}{l}\text { There is an operational strategy for } \\
\text { sustainability- related research, } \\
\text { development, and innovation projects in } \\
\text { cooperation with industries, business firms, } \\
\text { educational institutions or pertinent } \\
\text { organizations. }\end{array}$ & $\begin{array}{l}\text { As above, evidence can be found in internal and } \\
\text { external publications, reports, articles, etc. Such } \\
\text { material is in print and/or electronic media. }\end{array}$ \\
\hline $4 g$ & $\begin{array}{l}\text { Results of sustainability research, } \\
\text { development \& innovation projects are } \\
\text { communicated to the students; this serves } \\
\text { to enrich the curriculum and to stimulate } \\
\text { student interest. }\end{array}$ & $\begin{array}{l}\text { Evidence may be found in selected examples of } \\
\text { course descriptions and student projects in which } \\
\text { sustainability research content has become part of } \\
\text { the learning experience. }\end{array}$ \\
\hline $4 \mathrm{~h}$ & $\begin{array}{l}\text { The provision for sustainability-related } \\
\text { research, innovation, and cooperation is } \\
\text { sustainable in itself; i.e., adequate funding, } \\
\text { research and project management support } \\
\text { (including the initial pursuit of grants and } \\
\text { subsidies) }\end{array}$ & $\begin{array}{c}\text { There is evidence that sustainability research \& } \\
\text { development activities can be sustained; i.e., a } \\
\text { budget that is commensurate with objectives, } \\
\text { capable personnel, a business plan, and } \\
\text { preferably, the support of an institutional office for } \\
\text { research management. Existing management } \\
\text { documents or excerpts of them support the } \\
\text { argument }\end{array}$ \\
\hline
\end{tabular}

APINI members have carried out a number of applied environmental studies dealing directly or partly with sustainability issues. A substantial share of these studies has been ordered by the Ministry of Economy of 
the Republic of Lithuania. Apart of that, APINI has contacts with various partners in Lithuania and abroad, like universities, research institutions, NGOs, authorities and international organisations. APINI also aims to promote SRSE issues among students, as well as staff members, through environmental non-curricular on-campus activities. For example, APINI initiated waste recycling campaign "Žalieji Rūmai" ("Green University Building") in 2010 and "Žaliasis Universitetas" ("Green University") in 2012. "Žaliasis Universitetas" is the first environmental campaign that was launched for the whole campus. APINI has participated and invited its students to participate in the biggest environmental community campaign in Lithuania "Darom" ("Let's do it") for cleaning territories from waste.

The Institute of Environmental Engineering was awarded one of the highest rankings' (Fig. 1) and has become a fertile basis for a larger pilot project at university level. Programs and institute staff facilitated the development of the entire university as a model for sustainable operations, research and study, sustainable regional development.

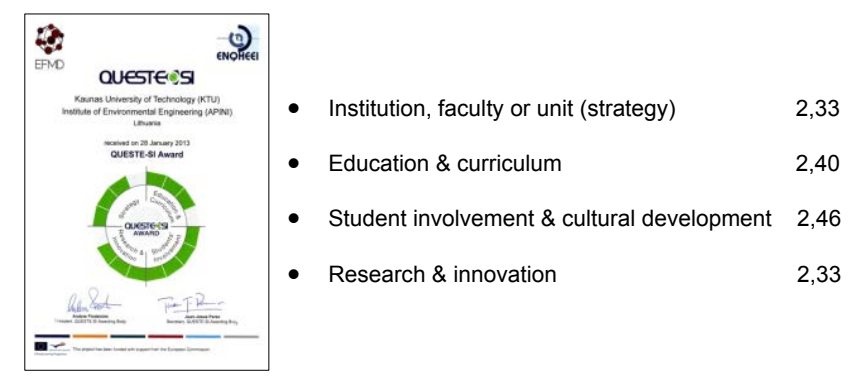

Figure 1: QUESTE-SI certificate

Fifteen institutions have participated in the final evaluation and accreditation phase. QUESTE-SI has no plans for publication of these evaluation ratings in a way that might inspire competitive rankings. There is an intention to help the institutions and map their strengths and limitations of programs and activities. The average evaluation of institutions according each dimension is presented below (the maximum rate -4 ) (see Figure 1).

The Institute of Environmental Engineering at KTU has received the QUESTE-SI label with a score of 3 in three dimensions and 4 in one dimension. Level 3, as defined by the label, corresponds to an institution unit which demonstrates a high quality level in the dimension. Level 4 demonstrates outstanding quality and can be considered as a model of excellence.

\section{CONCLUSIONS AND CONSIDERATIONS}

It is difficult to understand how an institution that delivers sustainable education might not be sustainable itself. That's why according QUESTE-SI, the high education institution should be a model of sustainable operations, research and development, and sustainability culture. The evaluation considers the institution and unit rationale for its choice of objectives, the actions taken, and the extent to which objectives have been realized.

The non-ranking objective of the QUESTE-SI will facilitate good practice exchanges among evaluated institutions and it will be beneficial not only for institution evaluated, which will get a more objective view on its strengths and weaknesses, but for the evaluators as well who will be able to identify best practices possibly useful for their own institutions. Comparatively low average QUESTE-SI evaluation rate shows that even in advanced high education institutions the leadership is rather light. There is a complex management challenge, i.e. to overcome possible conflicting and restraining forces and face resistance to changes.

Even if teachers' or researchers' individual initiatives are often promoted, quality assurance processes should help to promote interdisciplinary approach integrating sustainability issues in research and curricula, campuses, and institution strategies and vision. QUESTE-SI process has revealed that students 
could be good stakeholders in the quality assurance process. Besides their experience in learning and in campus, they can strongly influence the process via a bottom-up approach in all types of institution's activities towards sustainability and social responsibility.

\section{References}

Azapagic, A., Perdan, S., Shallcross, D. 2005. How much do engineering students know about sustainable development? The findings of an international survey and possible implications for the engineering curriculum. European Journal of Engineering Education, 30(1): 1-19.

Filho, W.L., Manolas, E., Pace, P. 2015. The future we want. Key issues on sustainable development in higher education after Rio and UN decade of education for sustainable development. International Journal of Sustainability in Higher Education, 16(1):113-129.

Jain, S., Aggarwal P., Sharma, N., Sharma, P. 2013. Fostering sustainability through education, research and practise: a case study of TERI University. Journal of Cleaner Production, 61: 20-24

Lee, K-H., Barker, M., Mouasher, A. 2013. Is it even espoused? An explanatory study of commitment to sustainability as evidenced in vision, mission, and graduate attribute statements in Australian universities. Journal of Cleaner Production, 48: 20-28.

Lozano, R., Lukman, R., Lozano, F.J., Huisingh, D., Lambrechts, W. 2013. Declarations for sustainability in higher education: becoming better leaders, through addressing the university system. Journal of Cleaner Production, 48: 10-19.

Lozano, R., Young, W. 2013. Assessing sustainability in university curricula: exploring the influence of student numbers and course credits. Journal of Cleaner Production, 49: 134-141.

Lozano, R. 2006. Incorporation and institutionalization of SD into universities: breaking through barriers to change. Journal of Cleaner Production, 14 (9): 787-796.

Lourdel, N., Gondran, N., Laforest, V., Brodhag, C. 2005. Introduction of sustainable development in engineers' curricula. Problematic and evaluation methods. International Journal of Sustainability in Higher Education, 6(3): 254-264.

Nejati, M., Nejati, M. 2013. Assessment of sustainable university factors from the perspective of university students. Journal of Cleaner Production, 48: 101-107.

Nesbit, E.S., Cruickshank, H.J., Nesbit, C.J. 2013. Educational principles for engineering education for sustainable development: experiences from U.K. and Canada. Proceedings of Engineering Education for Sustainable Development EESD13, 22-25 September 2013, Cambridge UK. Paper 69.

Philips, T., Budkowski, S. 2010. QUESTE-SI: Kit for Advisors, Quality referents and Auditors. Erasmus, EFMD.

Quality system of European Scientific and Technical Education - Sustainable Industry (2010 -2013). Project founded with the support from the European Commission, N 5100682-LLP-1-2010-BEERASMUS-EMHE and coordinated by EFMD. htttp://plone.queste.eu (consulted in September 2014).

Roorda, N. 2010. Sailing on the winds of change. The odyssey to sustainability by the universities of applied sciencesin the Netherlands. Ph.D thesis, Maastricht University.

Rouvrais, S., Le Locat, C., Flament, S. 2014. Return on experience from sustainability audits in European engineering educational institutions. SEFI 2013: 41th annual Conference: Engineering educational institutions, Sep 2013, Leuven, Belgium. pp.197. <hal-00965116>

Sauve, L. 1996. Environmental education and sustainable development: a further appraisal. Canadian Journal of Environmental Education, 1: 7-33.

Shi, H., Lai, E. 2013. An alternative university sustainability rating framework with a structured criteria tree. Journal of Cleaner Production, 61: 59-69.

Staniškis, J., K. 2012. International M.Sc. programme "Environmental Management and Cleaner Production: Success story" In: Sustainable development at Universities: New Horizons. Leal Filho, W (Ed.). Peter Lang Scientific Publishers, Frankfurt.

Suwartha, N., Sari, R.F. 2013. Evaluating UI GreenMetric as a tool to support green universities development: assessment of the year 2011 ranking. Journal of Cleaner Production, 61: 46-53.

Watson, M.K., Lozano, R., Noyes, C., Rodgers, M. 2013. Assessing curricula contribution to sustainability more holistically: experiences from the integration of curricula assessment and students' perceptions at the Georgia Institute of Technology. Journal of Cleaner Production, 61: 106-116. 